\title{
Transcriptomic analysis of Verbena bonariensis roots in response to cadmium stress
}

\author{
Meng-qi Wang ${ }^{1 \dagger}$, Zhen-yu Bai ${ }^{1 \dagger}$, Ya-fang Xiao ${ }^{1}$, Yan Li ${ }^{2 *}$, Qing-lin Liu ${ }^{1 *}$ (D) Lei Zhang ${ }^{1}$, Yuan-zhi Pan", \\ Bei-bei Jiang ${ }^{1}$ and Fan Zhang ${ }^{1}$
}

\begin{abstract}
Background: Cadmium (Cd) is a serious heavy metal (HM) soil pollutant. To alleviate or even eliminate HM pollution in soil, environmental-friendly methods are applied. One is that special plants are cultivated to absorb the HM in the contaminated soil. As an excellent economical plant with ornamental value and sound adaptability, $\mathrm{V}$. bonariensis could be adapted to this very situation. In our study, the $\mathrm{Cd}$ tolerance in $\mathrm{V}$. bonariensis was analyzed as well as an overall analysis of transcriptome.

Results: In this study, the tolerance of $V$. bonariensis to Cd stress was investigated in four aspects: germination, development, physiological changes, and molecular alterations. The results showed that as a nonhyperaccumulator, $V$. bonariensis did possess the $\mathrm{Cd}$ tolerance and the capability to concentration $\mathrm{Cd}$. Under $\mathrm{Cd}$ stress, all 237, 866 transcripts and 191, 370 unigenes were constructed in the transcriptome data of $V$. bonariensis roots. The enrichment analysis of gene Ontology (GO) and Kyoto Encyclopedia of Genes and Genomes (KEGG) pathway revealed that differentially expressed genes (DEGs) under Cd stress were predominately related to cell structure, reactive oxygen species (ROS) scavenging system, chelating reaction and secondary metabolites, transpiration and photosynthesis. DEGs encoding lignin synthesis, chalcone synthase (CHS) and anthocyanidin synthase (ANS) were prominent in $V$. bonariensis under Cd stress. The expression patterns of 10 DEGs, validated by quantitative real-time polymerase chain reaction (qRT-PCR), were in highly accordance with the RNA-Sequence (RNA-Seq) results. The novel strategies brought by our study was not only benefit for further studies on the tolerance of $\mathrm{Cd}$ and functional genomics in $\mathrm{V}$. bonariensis, but also for the improvement molecular breeding and phytoremediation.
\end{abstract}

Keywords: Verbena bonariensis, Cadmium stress, RNA-Seq, Physiological changes, Molecular mechanism

\section{Background}

HM pollution in soil has long jeopardized the sustenance of plants. As a kind of poisonous $\mathrm{HM}, \mathrm{Cd}$ served as a botanic destroyer [1]. Absorbed by roots, HMs in soil are transported to the aboveground parts of plants. The accumulation of HMs hampers the growth and

\footnotetext{
* Correspondence: yli@gzu.edu.cn; qinglinliu@126.com

${ }^{\dagger}$ Meng-qi Wang and Zhen-yu Bai contributed equally to this work and should be considered co-first authors.

${ }^{2}$ Institute of Agro-Bioengineering and College of Life Sciences, Guizhou University, Guiyang, Guizhou 550025, People's Republic of China

${ }^{1}$ Department of Ornamental Horticulture, Sichuan Agricultural University,

Chengdu, Sichuan 611130, People's Republic of China
}

development of plants. Accordingly, through food chain, this toxic matter endangers animals and human.

The excessive concentration of HMs has a severe impact on the growth, plasma membrane permeability, physiological and biochemical processes and nutritional status of plants [2]. The increased production of ROS under HM stress damages cell membranes, decomposes nucleic acids and declines photosynthesis of plants [3, 4]. ROS ruins balance between production and the activity of antioxidative system. $\mathrm{Cd}$ disrupts the growth and development of the plant by trespassing. The chelation is in response to HM stress in the plants. There are four main chelating agents in plants, including phytochelatin (PC), metallothionein (MT), organic acid and amino acid

(c) The Author(s). 2019 Open Access This article is distributed under the terms of the Creative Commons Attribution 4.0 International License (http://creativecommons.org/licenses/by/4.0/), which permits unrestricted use, distribution, and reproduction in any medium, provided you give appropriate credit to the original author(s) and the source, provide a link to the Creative Commons license, and indicate if changes were made. The Creative Commons Public Domain Dedication waiver (http://creativecommons.org/publicdomain/zero/1.0/) applies to the data made available in this article, unless otherwise stated. 
[5]. PCs plays an important role in detoxification of intolerable HMs to balance the internal metal elements. It is synthesized non-translationally from reduced glutathione $(\mathrm{GSH})$ in a transpeptidation reaction catalyzed by the enzyme PC synthase. The sensitivity of secondary metabolites to $\mathrm{HM}$ is species-specific [6]. The diversity as well as functions of soil microbial community structure were determined by the generation of root exudation in plants [7]. The study of 'Plants call for support' posed a hypothesis that the alteration of pollutioninduced root exudation aided the botanical selection of microbial communities to reduce the stress of the pollution to the root system [8]. It is suggested that to adapt to HM stress, metabolism is modified, along with the production of secondary metabolites, in plant tissues [9].

The RNA-Seq platform was used for the detection of plants under $\mathrm{Cd}$ stress. $\mathrm{Gu}$ et al. [10] investigate the transcriptome in Iris lactea var. chinensis under $\mathrm{Cd}$ and $\mathrm{Pb}$ stresses. Yongkun et al. [11] conducted a transcriptome analysis of $\mathrm{Cd}$ responses in Phytolacca americana $L$. Gao et al. [12] demonstrated that several genes involved in modifying cell wall and translocating metal ion had higher expressed levels in S. alfredii Hance shoots than that in non-hyperaccumulating ecotype shoots under exposing $\mathrm{Cd}$ stress. Similar results were also reported in Populus $\times$ canescens [13], Noccaea caerulescens [14], N. caerulescens [15], Viola yedoensis Makino [16] and Arabidopsis thaliana [17] using transcriptome analysis.

Due to strong adaptability, vigorous growth and highly ornamental value of $V$. bonariensis, especially with the popularity of sightseeing farms, it owned the potential in large scale cultivation. Therefore, the rehabilitation ability of $V$. bonariensis under HM stress secured the spotlight. In this study, we investigated the germination, morphologic and physiologic response along with the $\mathrm{Cd}^{2+}$ accumulation in $V$. bonariensis. In addition, a highthroughput sequencing technique was applied to construct the transcriptome database of $V$. bonariensis under $\mathrm{Cd}$ stress. The molecular mechanism of transportation and detoxification of $\mathrm{Cd}$ was analyzed based on sequence annotation. This study would made contribution to the discovery of potential $\mathrm{Cd}$ defensive strategies in $V$. bonariensis.

\section{Results \\ The germination and cd accumulation in V. bonariensis under different cd concentration stress}

Table 1 showed that the influence of $\mathrm{Cd}^{2+}$ on the seed germination depended on its concentration. Germination rate and Germination index (GI) was higher at 20 $\mathrm{mg} / \mathrm{L}$ than that of controlling groups. In $20 \mathrm{mg} / \mathrm{L}$ and below, vigor index (VI) and fresh weight were promoted on various degrees. At $14 \mathrm{~d}$, all the seedlings treated with over $50 \mathrm{mg} / \mathrm{L}$ concentrations of $\mathrm{Cd}$ died.

The contents of $\mathrm{Cd}$ in the shoots and roots increased with $\mathrm{Cd}$ concentration and time, while the $\mathrm{Cd}$ contents in roots were significantly higher than those in the shoots (Fig. 1a, b). When the Cd concentration in the soil increased to $400 \mathrm{mg} / \mathrm{kg}$ (T5) for $30 \mathrm{~d}$, Cd content reached the maximum, $133.11 \mathrm{mg} / \mathrm{kg}$, in whole plants (Fig. 1c). According to Fig. 2a, the minimum bioaccumulation factor (BCF) (at the root of the plant) was in proportion to duration and concentration of $\mathrm{Cd}$ stress. The range of variation is 0.309 to 0.999 . According to Fig. 2b, translocation factor (BTF) reached to the maximum (0.3344) at the $50 \mathrm{mg} / \mathrm{kg} \mathrm{Cd}$ concentration. The absorption of HMs is one of the signaling indicators for the HM purifications of the hyperaccumulator. It could be found in Fig. 2c that under all concentration Cd absorption reached its peak at $30 \mathrm{~d}$. The maximum is $31.66 \mu \mathrm{g} /$ pot in the $300 \mathrm{mg} / \mathrm{kg}$ (T4).

\section{The morphological and physiological changes of $V$. bonariensis under $100 \mathrm{mg} / \mathrm{kg}$ cd stress}

According to the measurement of various morphological (Additional file 1: Figure S1; Additional file 2: Figure S2) and physiological (Additional file 3: Figure S3) indexes

Table 1 Effect of $\mathrm{Cd}$ concentration on germination of Verbena bonariensis

\begin{tabular}{|c|c|c|c|c|c|}
\hline \multicolumn{5}{|l|}{$7 d$} & \multirow{2}{*}{$\begin{array}{l}14 \mathrm{~d} \\
\text { Survival rate (\%) }\end{array}$} \\
\hline Concentration (mg/L) & Germination rate (\%) & Germination index & Vigor index & fresh weight per plant (mg) & \\
\hline 0 & $97.78 \pm 1.92^{\mathrm{ab}}$ & $25.33 \pm 0.29^{\mathrm{abc}}$ & $0.0532 \pm 0.0020^{\mathrm{abc}}$ & $2.10 \pm 0.10^{\mathrm{abc}}$ & $97.78 \pm 1.92^{\mathrm{ab}}$ \\
\hline 5 & $97.78 \pm 1.92^{\mathrm{ab}}$ & $25.67 \pm 0.29^{\mathrm{ab}}$ & $0.0573 \pm 0.0056^{\mathrm{a}}$ & $2.23 \pm 0.23^{\mathrm{a}}$ & $97.78 \pm 1.92^{\mathrm{ab}}$ \\
\hline 10 & $97.78 \pm 1.92^{\mathrm{ab}}$ & $25.67 \pm 0.58^{\mathrm{ab}}$ & $0.0574 \pm 0.0050^{\mathrm{a}}$ & $2.23 \pm 0.15^{\mathrm{a}}$ & $97.78 \pm 1.92^{\mathrm{ab}}$ \\
\hline 20 & $100.00 \pm 0.00^{\mathrm{a}}$ & $26.50 \pm 0.50^{a}$ & $0.0565 \pm 0.0025^{\mathrm{ab}}$ & $2.13 \pm 0.06^{\mathrm{ab}}$ & $98.89 \pm 1.92^{\mathrm{a}}$ \\
\hline 50 & $97.78 \pm 1.92^{\mathrm{ab}}$ & $25.50 \pm 1.50^{\mathrm{ab}}$ & $0.0494 \pm 0.0043^{\mathrm{bcd}}$ & $1.93 \pm 0.06^{\mathrm{bcd}}$ & $46.67 \pm 6.67^{b}$ \\
\hline 100 & $96.67 \pm 5.77^{\mathrm{ab}}$ & $24.83 \pm 0.77^{\mathrm{bcd}}$ & $0.0471 \pm 0.0011^{\mathrm{cd}}$ & $1.90 \pm 0.10^{\mathrm{bcd}}$ & $0.00 \pm 0.00^{c}$ \\
\hline 150 & $95.56 \pm 1.93^{\mathrm{ab}}$ & $24.00 \pm 1.00^{c d}$ & $0.0449 \pm 0.0069^{d}$ & $1.87 \pm 0.21^{\mathrm{cd}}$ & $0.00 \pm 0.00^{c}$ \\
\hline 200 & $92.22 \pm 5.09^{b}$ & $23.50 \pm 0.50^{d}$ & $0.0423 \pm 0.0009^{d}$ & $1.80 \pm 0.00^{d}$ & $0.00 \pm 0.00^{c}$ \\
\hline
\end{tabular}

Note: Data represent means \pm SE of three replicates. The different letters above the columns express significant differences $(P<0.05)$ on the basis of Duncan's multiple range test 

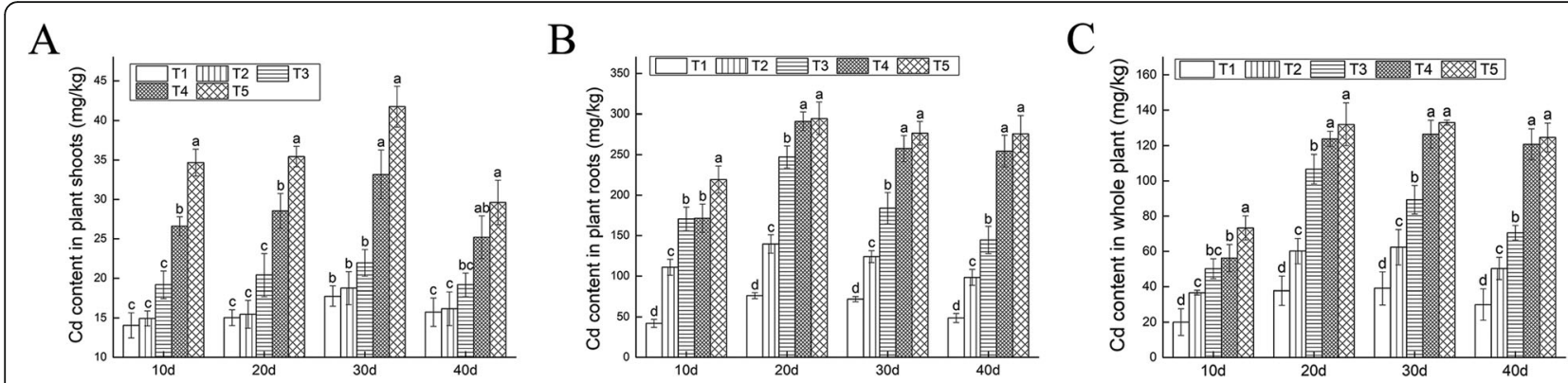

Fig. 1 Enrichment of $\mathrm{Cd}$ in plants. a Cd content in plant shoots. b Cd content in plant roots. c Total Cd content in Verbena bonariensis. A total of $50 \mathrm{mg} / \mathrm{kg}$ (T1), $100 \mathrm{mg} / \mathrm{kg}$ (T2), $200 \mathrm{mg} / \mathrm{kg}$ (T3), $300 \mathrm{mg} / \mathrm{kg}$ (T4), and $400 \mathrm{mg} / \mathrm{kg}$ (T5) were set up for $5 \mathrm{Cd}$ concentrations. Standard error of the mean for three repetitions is represented by the error bars. The different letters above the bars indicate the significant difference at $P<0.05$ among the different treatments. The same below

in the prophase, the seedlings treated in $100 \mathrm{mg} / \mathrm{kg}$ solution was selected for RNA-Seq. The morphological and physiological changes of the plants treated respectively under the control group (CK) and $100 \mathrm{mg} / \mathrm{kg} \mathrm{Cd}$ concentration for $20 \mathrm{~d}$ were compared.

The dwarf plants, yellow leaves, slight dark roots were inspected on Fig. 3a. A large amount of $\mathrm{H}_{2} \mathrm{O}_{2}$ and $\mathrm{O}_{2}{ }^{-}$ produced in leaves were observed on Fig. 3b. The petiole length (PL), the root length (RL), number (RN) and dry to fresh ratio $(\mathrm{Dw} / \mathrm{Fw})$ were significantly reduced by 17.39 , $31.87,35.29$ and $27.92 \%$, respectively. The height of upper part (HP) and leaf area (LA) declined slightly. All morphological indexes declined (Fig. 3c). The content of lignin and anthocyanidin (Fig. 4), the activity of ANS and CHS were higher than that of the control (Fig. 5). $\mathrm{Cd}^{2+}$ increased the content of malondialdehyde (MDA) and proline (PRO) as well as the GSH activity in leaves and roots. The superoxide dismutase (SOD), peroxidase (POD), catalase (CAT) and ascorbate peroxidase (APX) were elevated in leaves while decreased in roots under Cd stress (Fig. 6). Net photosynthetic rate (Pn), stomatal conductance (Gs), transpiration rate $(\mathrm{Tr})$, Chlorophyll a (Chla) and chlorophyll $b(\mathrm{Chlb})$ decreased on various degrees. $\mathrm{CO}_{2}$ concentration (Ci) slightly increased (Fig. 7).

\section{Sequence analysis and assembly}

Large amounts of data were produced by sequencing the two libraries ( $\mathrm{CK}$ and $\mathrm{Cd}$ ) of $V$. bonariensis with the
Illumina HiSeq 2500. After data filtering, a total of 55, 962, 351 and 61, 462, 567 clean reads with 93.33 and 93.36\% Q30 bases were selected for the CK and Cd libraries, respectively. With the Trinity program, all 237, 866 transcripts and 191, 370 unigenes with an average length of $1103 \mathrm{bp}$ and $1298 \mathrm{bp}$ were constructed in total. Data files obtained by Illumina HiSeqTM was submitted to the NCBI database with accession number GSE113569.

\section{Sequence annotation and classification}

Compared with the public seven databases, a total of 153, 895 (80.41\%) annotative unigenes were obtained. The successful rate of the functional annotation in the seven databases was shown in (Additional file 4: Figure S4). Sesamum indicum $(97,567$ unigenes) offered a prior similarity with V.bonariensis, then did the Erythranthe guttata $(20,692)$.

Using the GO annotation database, a total of 101, 415(52.99\%) unigenes were annotated and there were $50.98 \%$ in Biological process (BP), 35.44\% in Cellular component (CC), and $13.57 \%$ in Molecular function (MF) (Additional file 5: Figure S5). In all three data sets, 'cellular process', 'metabolic process' and 'single-organism process' were the most highly represented under BP; 'cell', 'cell part' and 'organelle' terms were dominant in $\mathrm{CC}$, and 'binding' and 'catalytic activity' were the most significant terms in the MF. Using the KEGG database, a
A

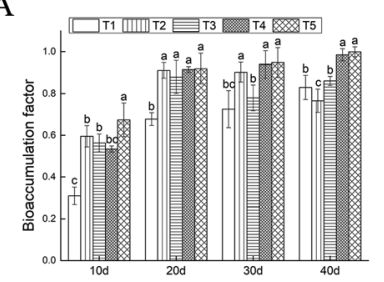

B

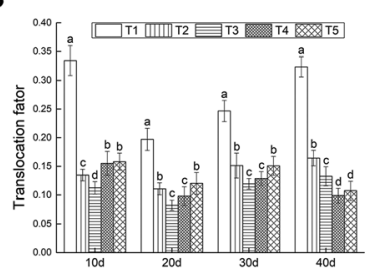

C

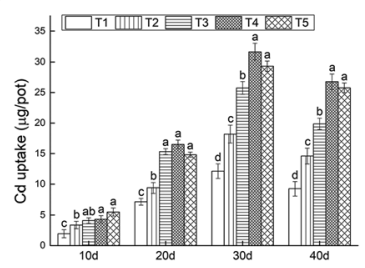

Fig. 2 The impacts of $\mathrm{Cd}$ in soil on the bioaccumulation factor, translocation factor and Cd uptake of Verbena bonariensis. a bioaccumulation factor of $\mathrm{Cd}$ in roots. $\mathbf{b}$ translocation factor of $\mathrm{Cd}$ in Verbena bonariensis. $\mathbf{c} \mathrm{Cd}$ uptake by Verbena bonariensis 


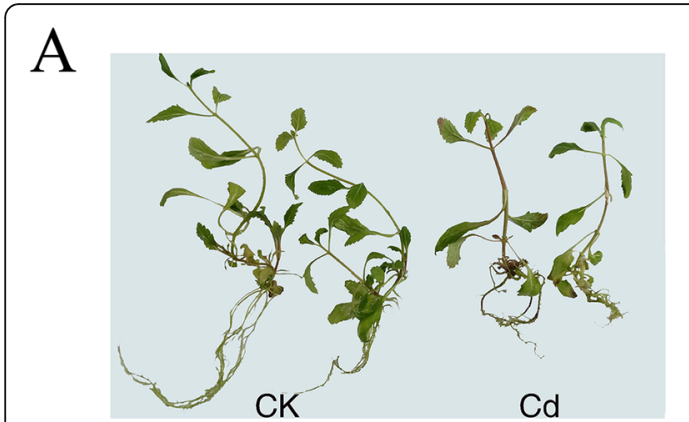

B
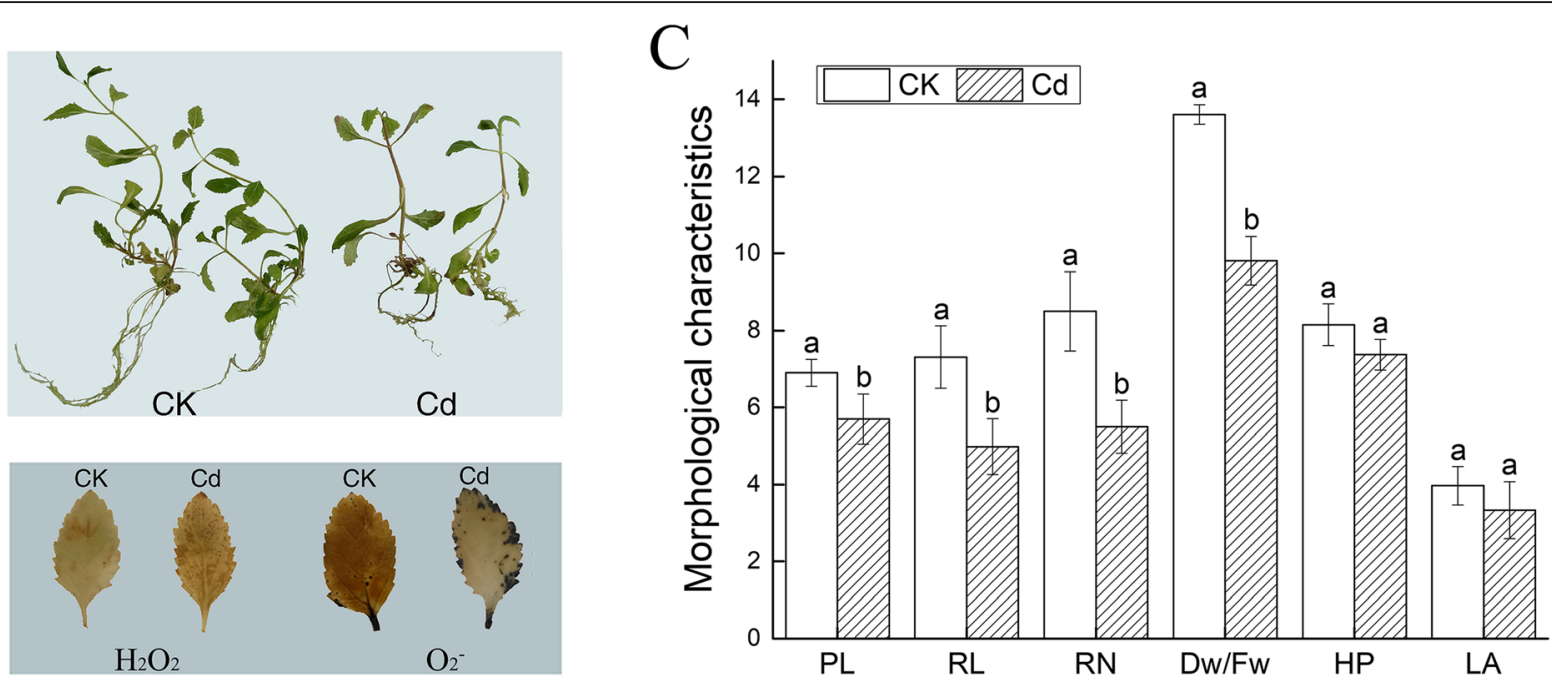

Fig. 3 Effects of $\mathrm{Cd}$ stress on external morphology and active oxygen metabolism in Verbena bonariensis. a The comparison of vitro morphology of plants from CK and Cd treated. b The comparison of ROS staining of leaves from control and Cd-treated Verbena bonariensis plants. $\mathbf{c}$ The indexes of morphological characteristics. Plants were grown with $100 \mathrm{mg} / \mathrm{kg} \mathrm{Cd}$ for $20 \mathrm{~d}$

total of 57,061 unigenes were grouped into five branches. Among these pathways, 'Carbohydrate metabolism' was the group with the greatest number of genes (5164, 9.06\%), followed by 'Translation' (4284, 7.50\%) and 'Folding, sorting and degradation' (3767, 6.60\%).

\section{Analysis of GO term and KEGG pathway involving DEGs}

In order to further understand the alteration in gene expression of $V$. bonariensis responding to Cd stress, differential expression analysis with DEGseq was performed. All 23, 424 DEGs were obtained, of which 12,558 were up-regulated while 10,866 were downregulated under $\mathrm{Cd}$ treatment.

A total of 16,580 DEGs in $V$. bonariensis were enriched in $60 \mathrm{GO}$ terms. BP, CC and MF accounted for $55.28,12.83$ and $28.65 \%$, respectively. Among the top 15

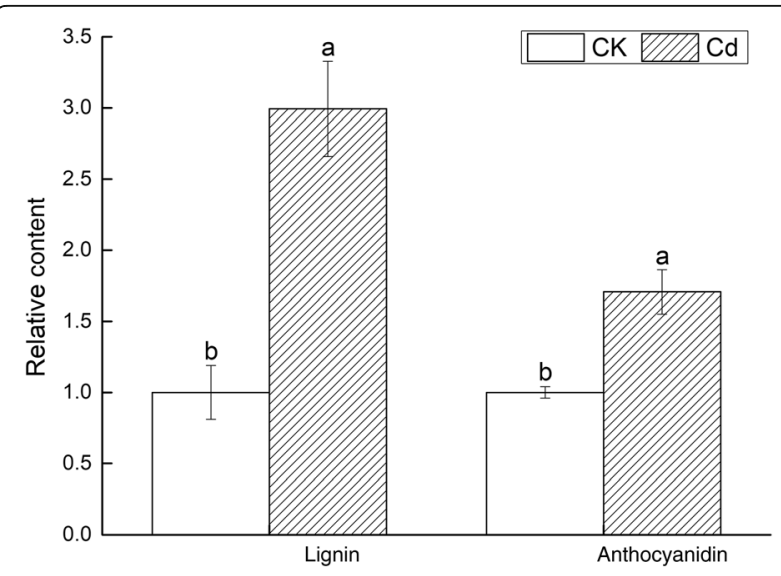

Fig. 4 The relative content of lignin and anthocyanidin significantly enriched GO terms for DEGs, seven GO terms were related to cell wall (Table 2).

A total of 8600 DEGs were assigned to 124 KEGG pathways. Table 3 showed the top-ten significant upregulation and down-regulation pathways involving DEGs, respectively. In top-ten up-regulated pathways, the 'glutathione metabolism' was the most significantly up-regulated pathway. All 133 DEGs were up-regulated and accounted for $76 \%$ of all DEGs of this pathway. There were three pathways relating to organic acid metabolism in top-ten up-regulated pathway, including 'Citrate cycle (TCA cycle)' (88 up- and 10 downregulated DEGs), 'Glyoxylate and dicarboxylate metabolism' (82 and 40) and 'alpha-Linolenic acid metabolism' (60 and 23). The 'Photosynthesis-antenna proteins' and 'photosynthesis' were the first two significantly down-regulated pathways. In 'Photosynthesis-antenna

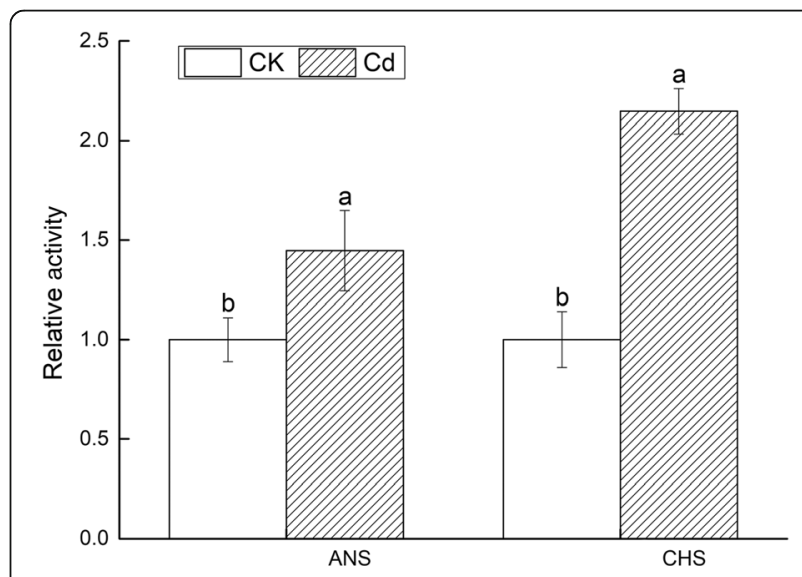

Fig. 5 The relative activity of ANS and CHS 


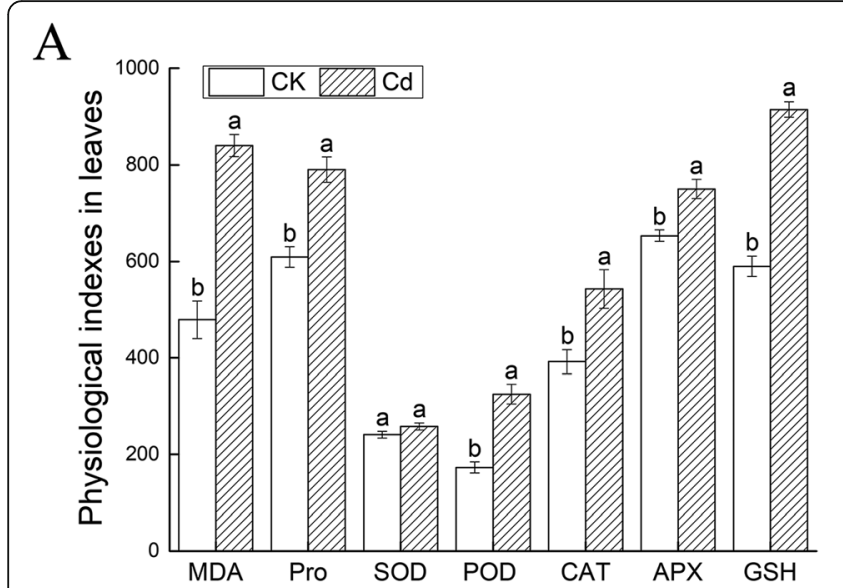

B

Fig. 6 Effects of $\mathrm{Cd}$ on physiological indexes of Verbena bonariensis. a The changes of leaves under $\mathrm{Cd}$ stress; $\mathbf{b}$ The changes of roots under $\mathrm{Cd}$ stress. SOD and APX activity as $\mathrm{u} \cdot \mathrm{g}^{-1}, \mathrm{POD}$ activity was expressed as $\mathrm{u} \cdot \mathrm{g}^{-1} \cdot \mathrm{min}^{-1}, \mathrm{CAT}$ as $10^{-1} \cdot \mathrm{u} \cdot \mathrm{g}^{-1} \cdot \mathrm{min}^{-1}, \mathrm{GSH}$ as $10^{-2} \cdot \mathrm{u} \cdot \mathrm{g}^{-1} \mathrm{FW}$, proline as $\mathrm{ng} \cdot \mathrm{ml}^{-1}$ and MDA as $10^{-1} \cdot \mathrm{nmol} \cdot \mathrm{L}^{-1}$

proteins' pathway, all 76 DEGs (75 down- and 1 upregulated DEGs) were related to the light-harvesting chlorophyll protein complex (LHC). Eighteen DEGs were related to Lhca, while 58 DEGs were involved in Lhcb. In 'Photosynthesis', only 9 genes in all 78 DEGs were up-regulated. In addition, the secondary metabolism pathway was worth mentioning. In 'phenylpropanoid biosynthesis', all the 18 DEGs associated with lignin synthesis was up-regulated (Additional file 6: Table S1). CHS (5 DEGs) and ANS (9) were related to flavonoid biosynthesis (Additional file 7: Table S2).

\section{qRT-PCR}

To confirm the reliability of high-throughput sequencing results, ten DEGs were selected and analyzed for qRT-

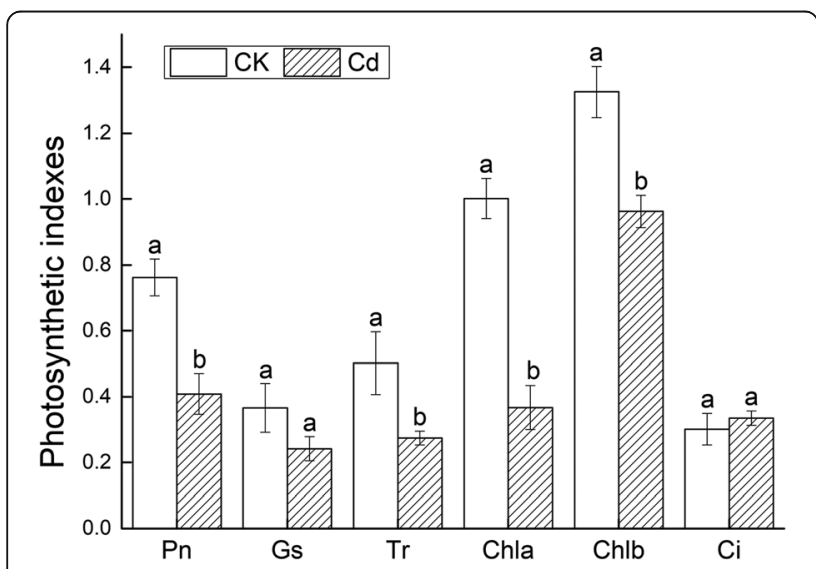

Fig. 7 Effects of photosynthesis under Cd stress in Verbena bonariensis leaves. $\mathrm{Pn}$ and $\mathrm{Tr}$ were expressed as $\mathrm{umol} \cdot \mathrm{m}^{-2} \cdot \mathrm{s}^{-1}$, Gs was expressed as $10^{-1} \cdot \mathrm{mol} \cdot \mathrm{m}^{-2} \cdot \mathrm{s}^{-1}, \mathrm{Ci}$ as $\mathrm{ml} \cdot \mathrm{L}^{-1}$, Chla and Chlb as $\mathrm{mg} \cdot \mathrm{g}^{-1}$
PCR. It proved that the fold variation between RNA-Seq expression and qRT-PCR analyses was almost the same (Fig. 8).

\section{Discussion}

The germination and morphological alteration of $V$. bonariensis under differential cd stress

During germinal and individual development, seeds was sensitive to environmental stress [18]. Therefore, the study on this stage reflected the tolerance to these stress in plants. Previous studies have demonstrated that 10 $\mathrm{mg} / \mathrm{L} \mathrm{Cd}$ concentration severely affected the germination of Medicago sativa [19]. Coreopsis drummondii and Impatiens walleriana Hook. $f$. seeds, compared with the controlling group, the germination rate of experimental group was reduced by about 50\% [20]. Our results showed that the threshold $\mathrm{Cd}$ concentration on $V$. bonariensis germination was about $50 \mathrm{mg} / \mathrm{L}$. Cd solutions within $20 \mathrm{mg} / \mathrm{L}$ concentration promoted the germination and growth on seedlings.

The growth and morphology alteration served as the basic adaptation mechanisms. The roots were suffered primarily from HMs in soil sites. Botanical growth was hindered, pigmentation, lateral root numbers, root activity were lessened. The absorption of water and nutrient utilization were disturbed [21]. With the HM ions shifted to shoot, the symptoms of toxicity altered: plant dwarfism, leaf chlorosis, reduced biomass, inhibited photosynthesis occurred, eventually death happened [22]. Under $\mathrm{Cd}$ stress, these changes were present in $V$. bonariensis (Fig. 3). Under Cd stress the roots elongation was severer inhibited than in the aboveground part of $V$. bonariensis, which was consistent with studies of Pinus sylvestris $L$ and hyperaccumulator S. nigrum [23, 24]. Petiole was the transportation channel of water and 
Table 2 The top-15 significant enriched GO terms involving DEGs under Cd stress

\begin{tabular}{llll}
\hline Description & Term_type & Up-regulated DEGs number & Down-regulated DEGs number \\
\hline structural constituent of cell wall & molecular_function & 101 & 3 \\
oxidation-reduction process & biological_process & 1354 & 802 \\
oxidoreductase activity & molecular_function & 1337 & 773 \\
plant-type cell wall organization & biological_process & 111 & 5 \\
plant-type cell wall organization or biogenesis & biological_process & 111 & 5 \\
catalytic activity & molecular_function & 5244 & 3879 \\
cell wall & cellular_component & 160 & 35 \\
external encapsulating structure & cellular_component & 181 & 48 \\
cell wall organization & biological_process & 145 & 21 \\
heme binding & molecular_function & 333 & 160 \\
tetrapyrrole binding & molecular_function & 333 & 167 \\
external encapsulating structure organization & biological_process & 148 & 21 \\
cell wall organization or biogenesis & biological_process & 187 & 40 \\
cell wall biogenesis & biological_process & 141 & 20 \\
single-organism metabolic process & biological_process & 2820 & 1954
\end{tabular}

nutrient from leaf to stem [25]. By speeding up the transportation of water and nutrients, the shorten petiole of $V$. bonariensis elevated the resistance to $\mathrm{Cd}$ stress. For leaf chlorosis, there existed two possible reasons: one was that the certain amount of $\mathrm{Cd}$ in the leaves rendered chlorophyll destruction and leaves chlorosis; the other was that due to the serious affliction to the root system and the malfunction of water transportation system, water shortage occurred in leaves. The above speculation was supported by the decrease of chlorophyll

Table 3 The top-ten significant enriched KEGG pathways involving DEGs under Cd stress

\begin{tabular}{|c|c|c|c|c|}
\hline Regulation & Pathway term & Rich factor & FDR & Gene number \\
\hline \multirow[t]{10}{*}{ Up-regulated } & Glutathione metabolism & 0.223529 & $2.42 \mathrm{E}-10$ & 133 \\
\hline & Citrate cycle (TCA cycle) & 0.226221 & $3.80 \mathrm{E}-07$ & 88 \\
\hline & Phenylpropanoid biosynthesis & 0.179342 & 9.83E-07 & 158 \\
\hline & Proteasome & 0.233974 & $1.13 \mathrm{E}-06$ & 73 \\
\hline & Carbon fixation in photosynthetic organisms & 0.180113 & 0.000261 & 96 \\
\hline & Glycolysis / Gluconeogenesis & 0.157366 & 0.001086 & 141 \\
\hline & Flavone and flavonol biosynthesis & 0.377778 & 0.00125 & 17 \\
\hline & Galactose metabolism & 0.169091 & 0.001704 & 93 \\
\hline & Glyoxylate and dicarboxylate metabolism & 0.172632 & 0.002082 & 82 \\
\hline & alpha-Linolenic acid metabolism & 0.180723 & 0.004917 & 60 \\
\hline \multirow[t]{10}{*}{ Down-regulated } & Photosynthesis - antenna proteins & 0.675676 & $2.18 \mathrm{E}-35$ & 75 \\
\hline & Photosynthesis & 0.345 & $1.82 \mathrm{E}-19$ & 69 \\
\hline & Glycerophospholipid metabolism & 0.16109 & $6.45 \mathrm{E}-12$ & 130 \\
\hline & Glycerolipid metabolism & 0.179704 & $6.71 \mathrm{E}-10$ & 85 \\
\hline & Carotenoid biosynthesis & 0.193133 & $3.94 \mathrm{E}-06$ & 45 \\
\hline & Ether lipid metabolism & 0.181818 & $3.94 \mathrm{E}-06$ & 50 \\
\hline & Circadian rhythm - plant & 0.178439 & $9.42 \mathrm{E}-06$ & 48 \\
\hline & Starch and sucrose metabolism & 0.112982 & 4.09E-05 & 161 \\
\hline & Vitamin B6 metabolism & 0.301587 & 4.65E-05 & 19 \\
\hline & Plant hormone signal transduction & 0.108998 & 0.000395 & 149 \\
\hline
\end{tabular}




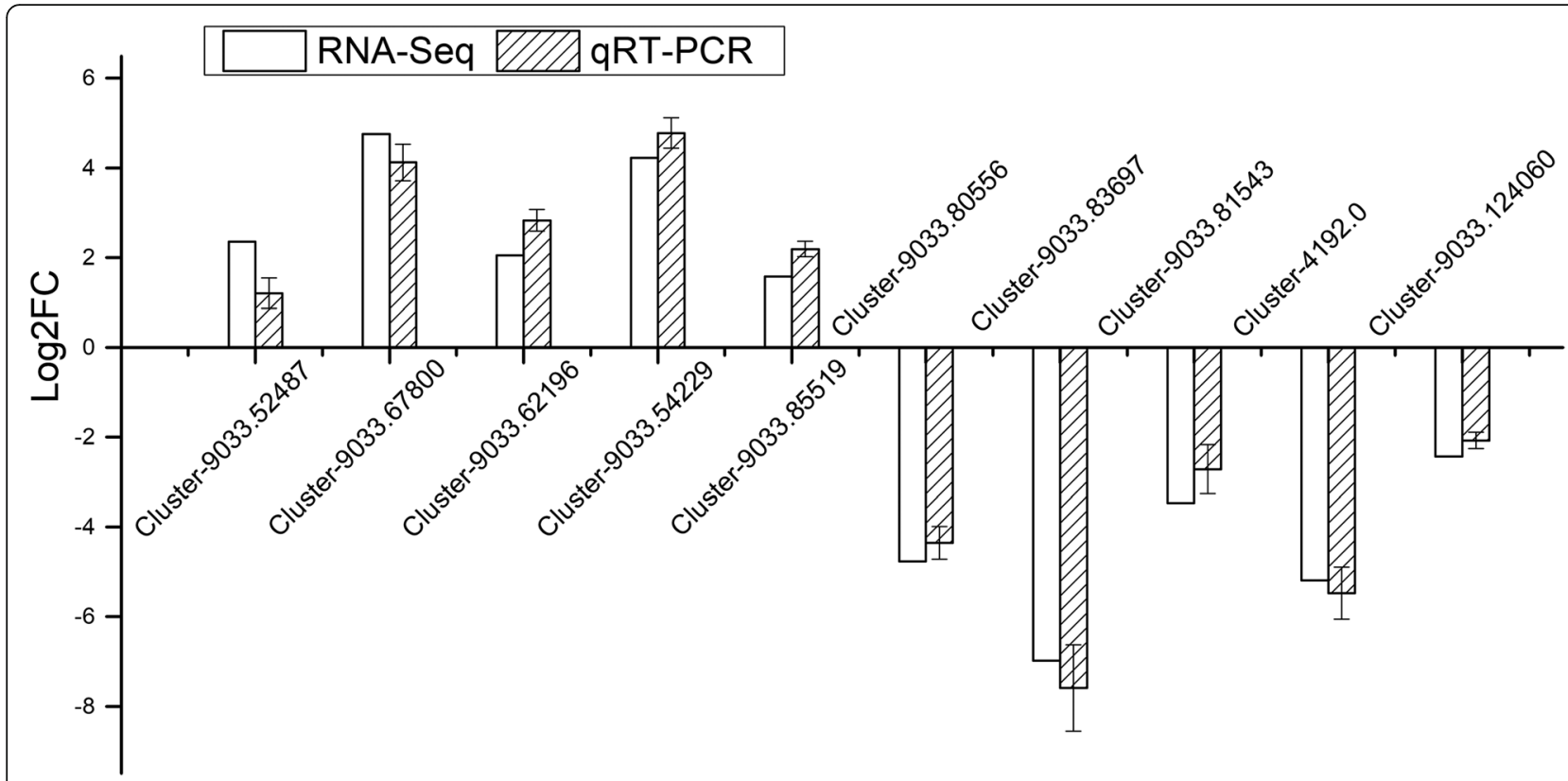

Fig. 8 Validation of RNA-Seq results using qRT-PCR. The gene primers used for RT-qPCR analysis are shown in Additional file 7: Table S2. Standard error of the mean for three repetitions is represented by the error bars

content, petiole length, leaf area, root length and number in $V$. bonariensis (Fig. 3c).

\section{$\mathrm{Cd}$ accumulation and transportation in V. bonariensis}

Typically, most positively charged HM ions tended to bind negative-charged compounds in tissues. Consequently, these ions accumulated in roots [26]. In our results, $\mathrm{Cd}$ accumulation in roots was significantly higher than that in aboveground parts, for the retention on $\mathrm{Cd}^{2+}$ in root system. Through $\mathrm{Cd}$ enrichment in root, $\mathrm{Cd}^{2+}$ were prevented from interrupting photosynthesis and metabolism in plants. Consequently, botanical survival under stress could be possible. The biomass of $V$. bonariensis were significantly reduced in $100 \mathrm{mg} / \mathrm{kg} \mathrm{Cd}$ solution. This very consistency was significantly higher than the critical concentration of $S$. nigrum, Cd stress over $25 \mathrm{mg} / \mathrm{kg}$ inhibited the growth of S.nigrum and decreased its biomass (Additional file 1: Figure S1) [27]. BCF indicated the transportation difficulty of HM elements in soil plant system [27]. The transportation and accumulation level of HMs from plant roots to the upper part of the plant were assessed by the BTF. For a hyperaccumulator, the BCF and BTF should be greater than 1 (Fig. 2a, b). The results proved that $V$. bonariensis showed no sign of hyperaccumulator. The absorption amount of $\mathrm{Cd}$ was $31.66 \mu \mathrm{g} /$ pot in $V$. bonariensis (Fig. 2c). By contrast, Cd hyperaccumulator Bidens pilosa L. was only $17.92 \mu \mathrm{g} /$ pot [27].

Based on the research results, $V$. bonariensis did not meet the standard of $\mathrm{Cd}$ hyperaccumulator. However, it had strong tolerance and absorption ability to $\mathrm{Cd}$. A large amount of $\mathrm{Cd}$ was accumulated in roots of $V$. bonariensis under $\mathrm{Cd}$ stress. Consequently, the reduced amount of $\mathrm{Cd}$ in leaves and other sensitive organs cast lighter toxic effects on plants. This was consistent with the results of the study that Lonicera Japanica Thunb [28] and Helianthus annuus [29]. In brief, with rapid growth capability, large biomass, strong Cd tolerance and absorption ability, $V$. bonariensis possessed potential application value in the remediation of $\mathrm{Cd}$ pollution.

\section{Effects of cd stress on cell wall and cell membrane of $V$. bonariensis}

The cell wall weighed significantly in botanical HM defense and detoxification [30]. As the first HMs barrier, it was firstly affected by $\mathrm{Cd}^{2+}$. The cell wall and carbohydrates protected $\mathrm{Cd}$ from entering roots by bounding it to the pectin site, which prevents HM ions from entering the protoplasm of the cell and protecting it from harm [31]. When exposed to HMs, the cell wall could activate hundreds of specific stress-responsive signaling proteins to protect the cell from crashing into the protoplast on susceptible sites. The lignin had a strong adsorption capacity for HM ions because it means a lot of radical groups, such as oxhydryl, methoxy and carbonyl group. The particle size of lignin was small, which was beneficial to the exposure of more radical groups and more HM ions could be adsorbed [32]. In our results, there were $7 \mathrm{GO}$ entries with cell wall tissue correlation, which suggested that $V$. bonariensis might increase its tolerance to HMs by combining the root cell wall with $\mathrm{Cd}^{2+}$. The lignin relating to phenylpropanoid pathway 
could reinforce specialized cell walls [33]. All 18 DEGs associated with lignin synthesis was up-regulated. The content of lignin under $\mathrm{Cd}$ stress was significantly higher than that of the control. This indicated that the cell wall of $V$. bonariensis might be reinforced and substantial $\mathrm{Cd}^{2+}$ in soil be absorbed under Cd stress.

The cell membrane served as the second barrier against trespassing of HMs. Cd was an important mutagen of plasma membrane peroxidation. MDA was induced by more ROS produced under $\mathrm{Cd}$ stress, causing membrane lipid peroxidation as well as destroying membrane ion channel structure [34]. The membrane lipid peroxidation in the cell of $V$. bonariensis was demonstrated by the significant elevation of MDA in leaves and roots under $\mathrm{Cd}$ stress.

\section{Effects of cd stress on ROS scavenging system in V. bonariensis}

Previous studies have shown that HM may injure plants by two biological pathways $[35,36]$. On one side, the HM stress oxidation inhibited the activity of protective enzyme. The main biological macromolecules such as proteins and nucleic acids were destroyed by the induced free radicals. On the other side, when absorbed into the plant, HM ion not only combined with nucleic acids, proteins, enzymes and other substances, but also supplant some specific elements exercising the function of enzymes and proteins, which make the related enzymes and proteins denature or reduce their activities. Under Cd stress, the ROS scavenging system played a vital role in plants. As the primary defense enzyme purging ROS in cell, SOD converted $\mathrm{O}_{2}{ }^{-}$disproportionation into $\mathrm{H}_{2} \mathrm{O}_{2}$ and eliminated $-\mathrm{OH}$ by catalyzing the Fenton reaction [37]. Cd stress is thought to elevate SOD activity in plants, but this promotion to SOD activity vary with $\mathrm{HM}$ treatment concentration and duration, plant species, and plant size [38]. In our study, the SOD activity in leaves and roots decreased under $\mathrm{Cd}$ treatment, it was speculated that excessive $\mathrm{Cd}^{2+}$ or stress time could inhibit the activity of SOD. Under Cd stress, the activities of POD, CAT and APX elevated in leaves of $V$. bonariensis. However, the results were opposite in roots. For its contact with soil, the roots were primarily susceptible to HM. Consequently, the stress level in roots was higher than that in leaves. When antioxidant enzyme activities in the root were hampered, the very activities in leaves continued coping with $\mathrm{Cd}$ stress. In the up-regulated GO enrichment categories relating to oxidative reactions, the enrichment degree of 'oxidation-reduction process', 'oxidoreductase activity' and 'catalytic activity' were high. The result showed that the oxidative reactions might be activated in response to Cd stress. By gearing the antioxidant system up, $V$. bonariens refrained from HM damage.
Effects of $c d$ stress on chelating reaction in $V$. bonariensis Upon exposure to HMs, plants synthesized diverse metabolites, particularly specific amino acids, such as PRO and histidine, peptides (glutathione and phytochelatins (PC) etc), and organic acids [39]. These matters mentioned above interacted with $\mathrm{Cd}^{2+}$ to form chelates, such compounds reduced the concentration of $\mathrm{Cd}^{2+}$ in soil. Furthermore, direct contact between $\mathrm{Cd}^{2+}$ and organelles were eliminated. Thereby the toxicity of $\mathrm{Cd}$ was reduced in soil.

Amino acid, as one of the plant's fundamental metabolites, counted great deal in the alleviation of HM stress. It served as integral part of the involved coenzyme and ligand in the metal complexation [40]. Cd stress resulted in a significant increase in the content of some amino acids, which might be a plant specific genetic trait. PRO regulated plant osmotic/redox reactions and participated in the metal complexation. In our study, $\mathrm{Cd}$ stress increased the accumulation of PRO in aboveground part by $29.76 \%$, whereas in roots the percentage was $4.68 \%$. Similarly, the amount of PRO in leaves was higher than that in roots of Bacopamonnieri under Cd stress [41].

For the great affinity to $\mathrm{HMs}$, PCs chelate various HMs to deactivation [42]. When the $\mathrm{Cd}^{2+}$ entered the cytoplasm through the cell wall and cell membrane, it combined with PC to form LMW complex, which was transferred into vacuole under the action of htm 1 membrane transportation protein. Then HMW complexes were synthesized by LMW and Cd, eventually immobilized in vacuole. The HMW complexes were less toxic to plants. PCs was a sulfhydryl polypeptide composed of cysteine, glutamic acid and glycine. As the precursor of PC synthesis, GSH composed some sulfur-containing compounds in root cells and $\mathrm{Cd}^{2+}$ to form stable chelates [43]. In our study, $76 \%$ of the DEGs involved in the 'glutathione metabolism' pathway was up-regulated. GSH content increased (Fig. 6). In this result, the promotion of PC content was predictable.

The organic acids of plants, such as oxalic acid, malic acid and citric acid, could be transformed the toxic $\mathrm{Cd}$ into low toxic or non-toxic form by chelating, promoting the tolerance of plants [44]. The pathways of organic acids in $V$. bonariensis were significant up-regulated in our results. It was estimated that the efficiency of organic acid synthesis was elevated. This promoted the binding of $\mathrm{Cd}^{2+}$ to organic acids in the cytoplasm or vacuoles, and alleviated the damage of HMs to $V$. bonariensis. The organic acids secretion capacity in $\mathrm{Cd}$ tolerant plants such as Rorippaglobosa was far greater than that in non-tolerant plants Rorippa [45]. The improvement of organic acid raised the soil acidity of the rhizosphere as well as reducing the $\mathrm{Cd}$ uptake by plants. Exposed to low concentration of $\mathrm{Cd}$, Bechmerianivea could secrete organic acids in its rhizosphere. With $\mathrm{Cd}$ 
chelating, the consistency of $\mathrm{Cd}^{2+}$ around the rhizosphere of Bechmerianivea decreased [46]. In transcriptome data of $V$. bonariensis under $C d$ stress, there were three pathways relating to organic acid metabolism among top-ten up-regulated pathway, including 'Citrate cycle', 'Glyoxylate and dicarboxylate metabolism' and 'alpha-Linolenic acid metabolism'. The result proved the significant function of organic acid metabolism in $V$. bonariensis under Cd stress.

\section{Effects of cd stress on secondary metabolites of $V$. bonariensis}

Although minor to plant growth and development, secondary metabolites were often involved in environmental stress [47]. The phenolic metabolism was an important process in plants' secondary metabolism. Under Abiotic stresses, a large number of phenolic compounds was induced to form mechanical barriers in order to prevent osmotic stress, or to remove excessive amounts of ROS in cells [48]. Most of the phenolic compounds were composed of flavonoids, simple phenols and quinones. The flavonoids, as an important botanical antioxidant, played a key role in resistance to stress [49]. The synthesis efficiency of flavonoids could be improved by the activation of peroxidase under $\mathrm{Cd}$ stress [50]. CHS and ANS relating to flavonoid biosynthesis belonged to the family of oxidoreductases. CHS was the first enzyme to spur phenylpropane metabolic pathway to conduct flavonoids synthesis. It served as a natural defense enzyme as well as a synthetic intermediate in plants [51]. Anthocyanin was a strong antioxidant, it can alleviate the toxicity of oxygen free radicals in plant cells. In our results, only one gene down-regulated in 5 CHS and 9 ANS genes, respectively. The content of anthocyanidin, the activity of CHS and ANS were significantly elevated. The results showed that CHS and ANS genes may play an important regulated role in $V$. bonariensis resist the damage of $\mathrm{Cd}$ stress.

The phenylpropanoid biosynthesis has been demonstrated to contribute to various aspects of plant biotic and abiotic responses [52]. The improvements of phenolic compound content under abiotic stress, particularly with respect to phenylpropanoid, have been extensively described [53]. In Lupinus luteus L., the phenylpropanoid pathway metabolites elevated $\mathrm{Pb}$ tolerance in its roots [54]. Occupied the third place in up-regulated pathway, the 'Phenylpropanoid biosynthesis' was essential under Cd stress in $V$. bonariensis (Table 3 ).

\section{Effects of cd stress on transpiration and photosynthesis in} V. bonariensis

Under Cd stress, the Tr of $V$. bonariensis decreased. The entrance of $\mathrm{Cd}^{2+}$ in guard cells through $\mathrm{Ca}^{2+}$ ion channel might induce stomatal closure through 'Abscisic acid' (ABA) pathway and inhibit transpiration in plants. These elements disturbed stomatal opening. In addition, $\mathrm{Cd}$ stress reduced the length and number of roots, limiting water intake (Fig. 3a). Therefore, the leaf area of $V$. bonariensis decreased to maintain water in cell. Similarly, $\operatorname{Tr}$ and leaf area of Brassica juncea were hampered under Cd stress [55].

$\mathrm{Cd}^{2+}$ damaged nucleoli in the cell of root tip, precluding the synthesis of RNA and the activities of RNAase, ribonuclease and proton pump. This process decreased nitrate reductase activity, reduced the uptake and transportation of nitrate from the root to the aboveground part. With the HM ions shifted to the upper part of plants, dwarfism and decreased biomass occurred. The upward transportation of nutrients was forestalled by the factors mentioned above. The lack of nutrients hindered photosynthesis and the growth of the plants. This action decreased photosynthetic rate, destroyed photosynthetic organs, damaged photosynthetic systems, disturbed carbon dioxide fixation, and even death [56].

In our experiment, $\mathrm{Pn}$ and $\mathrm{Gs}$ decreased whereas $\mathrm{CO}_{2}$ concentration (Ci) increased (Fig. 7). Stomatal and nonstomatal components were closely related to the Pn decrease [57]. Besides, as a non-stomatal limitation, chlorophyll decomposition accounted for the decline of Pn. The results illustrated that under $\mathrm{Cd}$ stress photosynthesis in $V$. bonariensis leaves were abated. As a result of Gs decline, $\mathrm{CO}_{2}$ supply decreased. The non-stomatal factors that hindered the utilization of $\mathrm{CO}_{2}$, resulted in the accumulation of intercellular $\mathrm{CO}_{2}$. Non-stomatal factors took a great to injure the chloroplast of $\mathrm{V}$. bonariensis under stress and decrease the photosynthetic cell activity.

In 'Photosynthesis-antenna proteins' pathway, only one gene encoding LHC was up-regulated. As a peripheral antenna system, antenna proteins in LHC elevated the efficiency of absorption of light energy [58]. Most of the DEGs associated with the 'Photosynthesis' were down regulated, indicating that $\mathrm{Cd}$ stress arose disorders in photosynthetic responses. Cd stress prevented light harvesting, electron transportation and carbon assimilation efficiency during photosynthesis in $V$. bonariensis. This was consistent with previous studies on the response of Maize to $\mathrm{Pb}$ [59]. These physiological and molecular changes suggested that down-regulation of the photosynthetic pathway might be a responsive step in $V$. bonariensis under Cd stress.

\section{Conclusions}

In this study, the $\mathrm{Cd}$ tolerance of $V$. bonariensis was exhaustively analyzed on physiological and molecular scales. The large-scale transcriptional data set of $V$. bonariensis in response to Cd stress was firstly obtained, $V$. bonariensis was identified as a HM tolerant plant in 
the first time. ROS system, transpiration and photosynthetic, secondary metabolism and Chelating reaction in $V$. bonariensis under $\mathrm{Cd}$ stress were understood by transcriptional data. Some promising DEGs that aided the tolerance to $\mathrm{Cd}$ in plants were found. In conclusion, our research will be beneficial for understanding the mechanism of $\mathrm{Cd}$ resistance in $V$. bonariensis. The clues for further studies on the relationships between plants and HMs in other Verbena plants were listed.

\section{Methods}

\section{Materials and germination experiment design}

$V$. bonariensis seeds were purchased from Germany Benary seed company. The treatment solution was prepared with deionized water and $\mathrm{CdCl}_{2} \cdot 2.5 \mathrm{H}_{2} \mathrm{O}$. The concentrations were $5 \mathrm{mg} / \mathrm{L}, 10 \mathrm{mg} / \mathrm{L}, 20 \mathrm{mg} / \mathrm{L}, 50 \mathrm{mg} / \mathrm{L}, 100 \mathrm{mg} /$ $\mathrm{L}, 150 \mathrm{mg} / \mathrm{L}, 200 \mathrm{mg} / \mathrm{L}$. The Reverses Osmosis (RO) pure water was used as controlling group. The two sheets of filter paper were placed in a culture dish of 9 $\mathrm{cm}$ in diameter. Ten milliliters of treatment solution were added to saturate filter paper. The wet filter paper was used as a bed for germination. Thirty seeds were placed in each dish, sorted to a total of three replicates. All experiments were performed three times to ensure biological repetitions. The dishes were placed in the incubator $\left(16 \mathrm{~h}\right.$ photoperiod, $25^{\circ} \mathrm{C} / 16^{\circ} \mathrm{C}$ day/night temperature). The culture dish was sealed with a sealing film to keep humidity. The germination condition was observed daily until the germination of the controlling group revealed unchanged. The incubation time was about 2 weeks.

Germination rate $(\%)=$ number of germinated seeds within 7 days/ total seed "100\%;

$\mathrm{GI}=\Sigma \mathrm{Gt} / \mathrm{Dt}$ (Gt for germination number of $\mathrm{t}$ days, $\mathrm{Dt}$ for corresponding days);

$\mathrm{VI}=\mathrm{GI}$ * biomass (the biomass was the fresh weight of individual seedling) [60].

\section{Cd treatment}

The robust plants with health growth were selected for soil Cd stress treatment. Seedling age was 30-day old. One seedling was planted in each plastic flowerpot. Fifteen pots were involved in each treatment. The perlite and peat soil (PINDSTRUP, DK) were mixed evenly at 1 : 1 (v: v) and sterilized with right amount of carbendazim. With 15-day air-dry, the mixed soil was put into the circular plastic flowerpot $(\mathrm{d}=12 \mathrm{~cm})$ on the standard of 1 $\mathrm{kg}$ per pot. The soil moisture content was controlled as $70 \%$ using the RO water (about $180 \mathrm{ml}$ ).

(1) Cd treatment of different concentration was designed. In order to obtain detailed and accurate data, the content of $\mathrm{Cd}$ in $V$. bonariensis was measured. A total of $50 \mathrm{mg} / \mathrm{kg}$ (T1), $100 \mathrm{mg} / \mathrm{kg}$ (T2), $200 \mathrm{mg} / \mathrm{kg}$ (T3), 300 $\mathrm{mg} / \mathrm{kg}$ (T4), and $400 \mathrm{mg} / \mathrm{kg}$ (T5) were set up for $5 \mathrm{Cd}$ concentrations. The CK were treated without $\mathrm{Cd}$ solution. Three seedlings were planted in each pot, each treatment with 10 pots. During the experiment, plants and soil samples were collected every 10 days for 4 times.

(2) Cd treatment for RNA-Seq was arranged. The experiment was repeated three times with a total of 90 pots. The $\mathrm{CK}$ were treated without $\mathrm{Cd}$ solution. The concentration of $\mathrm{Cd}$ in the experimental group was 100 $\mathrm{mg} / \mathrm{kg}$. $\mathrm{CdCl}_{2} \cdot 2{ }_{1} / 2 \mathrm{H}_{2} \mathrm{O}$ and $\mathrm{RO}$ water were mixed to form $150 \mathrm{ml} \mathrm{Cd}$ solution with different concentrations. The mix solution was applied evenly into the corresponding flowerpot on the first day. After 20 days under $\mathrm{Cd}$ stress, the roots were harvested. The root samples were immediately frozen in liquid nitrogen and stored at $-80^{\circ} \mathrm{C}$. In this experiment, the seedings were grown in ambient conditions with a photoperiod of $14 \mathrm{~h}$ at $25^{\circ} \mathrm{C}$ and a relative humidity of $75 \%$.

\section{Determination of $\mathrm{cd}$ in plants and soils}

Plant (root, stem and leaf) and soil samples were collected and dried. These samples were crushed. Then the samples were digested by $\mathrm{HNO}_{3}-\mathrm{HCLO}_{4}$ per $0.5 \mathrm{~g}$. The atomic absorption flame spectrophotometer was applied to determine the content of $\mathrm{Cd}$. All of the above experiments were repeated three times.

$$
\begin{aligned}
& \mathrm{BCF}=\mathrm{C}_{\text {plant }} / \mathrm{C}_{\text {soil }} ; \\
& \mathrm{BTF}=\mathrm{C}_{\text {overground part }} / \mathrm{C}_{\text {subterranean part }} ;
\end{aligned}
$$

In the formula, $\mathrm{C}_{\text {plant }}$ was the concentration of $\mathrm{HM}$ in a part (root, stem and leaf) of the plant $(\mathrm{mg} / \mathrm{kg}) ; \mathrm{C}_{\text {soil }}$ was the concentration of corresponding $\mathrm{HM}$ element in soil $(\mathrm{mg} / \mathrm{kg}) ; \mathrm{C}_{\text {overground part }}$ was the concentration of $\mathrm{HM}$ in the upper part of the plant $(\mathrm{mg} / \mathrm{kg}) ; \mathrm{C}_{\text {subterranean }}$ part was the concentration of HM in lower parts of plant $(\mathrm{mg} / \mathrm{kg})[61]$.

\section{Determination of morphological characteristics and physiological indexes}

The leaf and root samples were collected. Some of them was used for morphological measurement. Others were immediately frozen in liquid nitrogen and stored at $80^{\circ} \mathrm{C}$ for physiological measurements. Morphological features were measured according to $\mathrm{Bai}$ et al. [62]. Histochemical staining of $\operatorname{ROS}\left(\mathrm{H}_{2} \mathrm{O}_{2}\right.$ and $\left.\mathrm{O}_{2}{ }^{-}\right)$methods referred to Wang et al. [63]. The content of MDA was determined by thiobarbituric acid colorimetric assay proposed by Cakmak and Marschner [64]. Nitro-blue tetrazolium photoreduction method, Guaiacol method and Ultraviolet absorption method were used to determine the activity of SOD, POD and CAT, respectively [65]. APX activity was determined by reference to Nakano et al. and the $\mathrm{OD}_{290}$ changes were measured per minute [66]. The activity of GSH and the content of PRO were determined according to Quessada et al. [67] 
Table 4 qRT-PCR reaction system

\begin{tabular}{ll}
\hline Reagent & Quantity \\
\hline SsoFast EvaGreen supermix & $10 \mu \mathrm{l}$ \\
cDNA template & $2 \mu \mathrm{l}$ \\
Forward Primer (10uM) & $0.8 \mu \mathrm{l}$ \\
Reverse Primer (10uM) & $0.8 \mu \mathrm{l}$ \\
RNase/Dnase free water & $6.4 \mu \mathrm{l}$ \\
Total & $20 \mu \mathrm{l}$ \\
\hline
\end{tabular}

and Bates et al. [68], respectively. Blade gas exchange parameter was measured at nine o'clock in the morning and the endogenous light intensity was $800 \mu \mathrm{mol}$ quanta $\mathrm{m}^{-2} \mathrm{~s}^{-1}$ [69].

The content of lignin and anthocyanidin in roots was measured by referring to the method of Chang XF et al. [70] and Dedaldechamp et al. [71], respectively. The activity of chalcone synthase and anthocyanidin synthase in roots were measured by A Special Kit for the determination of Plant anthocyanin activity in TSZ Company of the United States.

RNA isolation, library construction and RNA-Seq analysis Roots with two different treatments were collected from $V$. bonariensis. RNA-Seq analysis were performed with three replicates. Total RNA isolation was performed with Trizol Reagent (Invitrogen) according to the manufacturer's protocol. RNA purity and concentration were checked using the NanoPhotometer spectrophotometer (IMPLEN, CA, USA) and Qubit ${ }^{\circ}$ RNA Assay Kit in Qubit ${ }^{\circ}$ 2.0 Flurometer (Life Technologies, CA, USA), respectively. In brief, mRNA was enriched from total RNA using poly-T-oligoattached magnetic beads. as template to synthesize double stranded cDNA, mRNAs were purified with AMPure XP beads (Beckman Coulter, Beverly, USA). the purified double stranded cDNA was subjected to terminal repair and then supplemented with A tail to connect sequencing connector. In order to select cDNA fragments of preferentially 150 200 bp in length, the library fragments were purified with AMPure XP system. At last, PCR was performed with Phusion High-Fidelity DNA polymerase, universal PCR primers and Index (X) Primer. The qualifed libraries assessed on the Agilent Bioanalyzer 2100 system were sequenced on an Illumina Hiseq2500 platform.

\section{Raw sequence procession, assembly and functional annotation}

After filtering, clean data was obtained. Transcriptome de novo assembly was accomplished using Trinity with min-kmer-cov set to 2 by default. A BLASTx search was used for further functional annotation of the unigenes against the NCBI non-redundant protein sequences $(\mathrm{Nr}), \mathrm{NCBI}$ nucleotide sequences $(\mathrm{Nt})$ and Swiss-prot with an $E$-value of $\leq 10^{-5}$, while compared with
euKaryotic Ortholog Groups (KOG) with an $E$-value of $\leq 10^{-3}$. The HMMER3 program was used to assign Protein family (Pfam) with an $E$-value $=0.01$. GO using Blast2GO v2.5 program with an $E$-value $=1 \mathrm{e}^{-6}$. According to the KEGG database, pathway assignments were carried out using BLASTx with $E$-value $=1 \mathrm{e}^{-10}$.

\section{The analysis of differential expression}

The input data of gene differential expression is the read count data obtained in the analysis of gene expression level. The read count data were standardized by trimmed mean of $M$-value. DESeq [72] was used to carry out the differential analysis. The Benjamini and Hochberg's approach [73] to control the False Discovery Rate (FDR) was applied to adjust $p$-value of the results. DEGs screening condition was FDR $<0.05$.

\section{qRT-PCR validation}

To further validate the DEGs identified in analysis of the RNA-Seq data, ten DEGs were selected randomly to perform qRT-PCR analysis with three replicates. The RNA from the isolated RNA sequencing samples mentioned above. The qRT-PCR reaction system was showed in Table 4. The PCR cycling conditions was $95^{\circ} \mathrm{C}$ for $30 \mathrm{~s}$, followed by 40 cycles of $95^{\circ} \mathrm{C}$ for $15 \mathrm{~s}$ and $60^{\circ} \mathrm{C}$ for $30 \mathrm{~s}$. The gene-specific primers were designed by Primer 5 . The Actin gene (F: GAAAGATGGCTGGAAGAGGG; R: GCTATGAACTCCCTGATGGTC) was served as a reference control to detect expression level of 10 DEGs. The primer sequences were shown in (Additional file 8: Table S3). The data was analyzed using the $2^{-\Delta \Delta C T}$ method.

\section{Statistical analysis}

The experimental data were statistically analyzed by SPSS17.0 (SPSS Inc., Chicago, USA). The significance test of difference was made by the LSD method, significance level setting $P=0.05$.

\section{Supplementary information}

Supplementary information accompanies this paper at https://doi.org/10. 1186/s12864-019-6152-9.

Additional file 1: Figure S1. Changes of Verbena bonariensis biomass under $\mathrm{Cd}$ different concentration stress.

Additional file 2: Figure S2. Changes of Verbena bonariensis morphological indexes under Cd different concentration stress. (a) Leaf area; (b) petiole long; (c) Plant height; (d) Root length; (e) Number of lateral roots.

Additional file 3: Figure S3. Changes of Verbena bonariensis physiological indexes under $\mathrm{Cd}$ different concentration stress. (a) POD activity; (b) SOD activity; (c) APX activity; (d) Soluble sugar content; (e) Soluble protein content; (f) PRO content; (g) GSH activity; (h) MDA activity.

Additional file 4: Figure S4. Unigenes notes success statistics in each database. 
Additional file 5: Figure S5. Unigenes classified statistics based on GO annotations.

Additional file 6: Table S1. DEGs encoding lignin synthesis in 'phenylpropanoid biosynthesis' pathway.

Additional file 7: Table S2. DEGs encoding chalcone synthase (CHS) and anthocyanidin synthase (ANS).

Additional file 8: Table S3. The primers of 10 DEGs and different parameters derived from qRT-PCR analysis.

\section{Abbreviations}

ABA: Abscisic acid; ANS: Anthocyanidin synthase; APX: Ascorbate peroxidase; BCF: Bioaccumulation factor; BP: Biological processes; BTF: Translocation factor; CAT: Catalase; CC: Cell Component; Cd: Cadmium; Chla: Chlorophyll a; Chlb: Chlorophyll b; CHS: Chalcone synthase; $\mathrm{Ci}$ : $\mathrm{CO}_{2}$ concentration; CK: control group; DEGs: Differentially expressed genes; FDR: False discovery rate; Gl: Germination index; GO: Gene ontology; Gs: stomatal conductance; GSH: Glutathione; HM: heavy metal; KEGG: Kyoto Encyclopedia of Genes and Genomes; KOG: EuKaryotic orthologous groups; MDA: Malondialdehyde; MF: Molecular function; MT: Metallothionein; Nr: NCBI non-redundant protein sequences; Nt: NCBI nucleotide sequences; PC: Phytochelatin; Pfam: Protein family; Pn: Net photosynthetic rate; POD: Peroxidase; PRO: proline; qRTPCR: Quantitative real-time polymerase chain reaction; RNA-Seq: RNASequence; RO: Reverses Osmosis; ROS: Reactive oxygen species; SOD: Superoxide dismutase; Tr: transpiration rate; Vl: Vigor index

\section{Acknowledgements}

All authors declare that they have no conflict of interest.

\section{Authors' contributions}

MQW, ZYB, LY and QLL conceived and designed the experiments. MQW, $Z Y B$, and YFX performed the experiments. MQW, LZ, Y-ZP, B-BJ and FZ analyzed the data. MQW. and ZYB. wrote the paper. All authors read and approved the final manuscript. MQW and ZYB contributed equally to this work and should be considered co-first authors.

\section{Funding}

The RNA-Seq analysis was supported by National Natural Science Foundation of China (31770742), Sichuan Science and Technology Program (2019YJ0512), Natural Science Foundation of Guizhou (20181044), the introduction of talent project of Guizhou University (201756) and Guizhou University cultivation project (20175788-33). The funding body had no role in the design of the study, the interpretation of data and in writing the manuscript.

\section{Availability of data and materials}

The raw sequencing data have been submitted to the NCBI Sequence Read Archive database with accession number GSE113569.

\section{Ethics approval and consent to participate}

Not applicable.

\section{Consent for publication}

Not applicable.

\section{Competing interests}

The authors declare that the research was conducted in the absence of any commercial or financial relationships that could be construed as a potential conflict of interest.

\section{Received: 6 June 2019 Accepted: 30 September 2019}

\section{Published online: 20 November 2019}

\section{References}

1. Thakur S, Choudhary S, Bhardwaj P. Comparative transcriptome profiling under cadmium stress reveals the uptake and tolerance mechanism in Brassica juncea. J Plant Growth Regul. 2019:1-12. https://doi.org/10.1007/ s00344-019-09919-8.

2. Liu SL, Pan YZ, Yang RJ, Ding JJ, Yang HE, Wang L, Ma MD. Effects of exogenous $\mathrm{NO}$ on mineral nutrition absorption,lipid peroxidation and ATPase of plasma membrane in Catharanthus roseus tissues under cadmium stress. J Plant Nutr Fertilizer. 2014;20(2):445-58. https://doi.org/10.11674/ zwyf.2014.0222

3. Ma XX, Yu DL, Shao WS, Xu M, Zuo ZW, Wang HZ, Meng YJ. Transcriptomewide identification and characterization of the copper and cadmium stressresponsive small RNAs and their targets in Arabidopsis thaliana. Plant Soil. 2018;429(1-2):391-405. https://doi.org/10.1007/s11104-018-3697-3.

4. Tewari RK, Kumar P, Sharma PN, Bisht SS. Modulation of oxidative stress responsive enzymes by excess cobalt. Plant Sci. 2002;162(3):381-8. https:// doi.org/10.1016/s0168-9452(01)00578-7.

5. Chen AK, Gong YL, Zhou XJ, Liu XH. Accumulation of $\mathrm{cd}$, as and their interaction with mineral elements in different rice (Oryza sativa L.) cultivars grown in Gejiu mine, Yunnan Province. Ecol Sci. 2013;32(3):668-72. https:// doi.org/10.1016/j.pnpbp.2007.11.016.

6. Molnár K, Farkas E. Current results on biological activities of lichen secondary metabolites: a review. Zeitschrift für Naturforschung C. 2010; 65(3-4):157-73. https://doi.org/10.1515/znc-2010-3-401.

7. Michalet S, Rohr J, Warshan D, Bardon C, Roggy JC, Domenach AM, et al. Phytochemical analysis of mature tree root exudates in situ and their role in shaping soil microbial communities in relation to tree $\mathrm{N}$-acquisition strategy. Plant Physiol Biochem. 2013;72(1):169-77. https://doi.org/10.1016/j.plaphy.2013.05.003.

8. Thijs S, Sillen W, Rineau F, Weyens N, Vangronsveld J. Towards an enhanced understanding of plant-microbiome interactions to improve phytoremediation: engineering the Metaorganism. Front Microbiol. 2016;7: 341. https://doi.org/10.3389/fmicb.2016.00341.

9. Singh S, Parihar $P$, Singh $R$, Singh VP, Prasad SM. Heavy metal tolerance in plants: role of Transcriptomics, proteomics, metabolomics, and lonomics. Front Plant Sci. 2016;6:1143. https://doi.org/10.3389/fpls.2015.01143.

10. Gu CS, Liu LQ, Deng YM, Zhang YX, Wang ZQ, Yuan HY, Huang SZ. De novo, characterization of the, iris lactea, var. chinensis, transcriptome and an analysis of genes under cadmium or lead exposure. Ecotoxicol Environ Saf. 2017;144:507-13. https://doi.org/10.1016/j.ecoenv.2017.06.071

11. Chen YK, Zhi JK, Zhang H, Li J, Zhao QH, Xu JC. Transcriptome analysis of Phytolacca americana $\mathrm{L}$. in response to cadmium stress. PLOS ONE. 2017; 12(9):e0184681. https://doi.org/10.1371/journal.pone.0184681.

12. Gao J, Sun L, Yang X, Liu JX, Schiefelbein J. Transcriptomic analysis of cadmium stress response in the heavy metal hyperaccumulator sedum alfredii hance. PLoS One. 2013;8(6):e64643. https://doi.org/10.1371/journal. pone.0064643.

13. He J, Li H, Luo J, Ma C, Li S, Qu L, et al. A transcriptomic network underlies microstructural and physiological responses to cadmium in Populus $\mathrm{x}$ canescens. Plant Physiol. 2013;162:424-39. https://doi.org/10.1104/pp.113.215681.

14. Milner MJ, Mitani-Ueno N, Yamaji N, Yokosho K, Craft E, Fei Z, et al. Root and shoot transcriptome analysis of two ecotypes of Noccaea caerulescens uncovers the role of NcNramp1 in cd hyperaccumulation. Plant J. 2014;78: 398-410. https://doi.org/10.1111/tpj.12480.

15. Lin YF, Severing El, Hekkert BTL, Schijlen E, Aarts MG. A comprehensive set of transcript sequences of the heavy metal hyperaccumulator Noccaea caerulescens. Front Plant Sci. 2014;5:261. https://doi.org/10.3389/fpls.2014.00261.

16. Gao J, Luo M, Zhu Y, He Y, Wang Q, Zhang C. Transcriptome sequencing and differential gene expression analysis in Viola yedoensis Makino (Fam. Violaceae) responsive to cadmium (cd) pollution. Biochem Biophys Res Commun. 2015;459:60-5. https://doi.org/10.1016/j.bbrc.2015.02.066.

17. Weber M, Trampczynska A, Clemens S. Comparative transcriptome analysis of toxic metal responses in Arabidopsis thaliana and the $\mathrm{Cd}^{2+}$-hypertolerant facultative metallophyte Arabidopsis halleri. Plant Cell Environ. 2006;29(5): 950-63. https://doi.org/10.1111/j.1365-3040.2005.01479.x.

18. Li M, Luo YM, Song J, Zhang DS. Ecotoxicological effects of pH, salinity and heavy metals on the barley root elongation in mixture of copper mine tailings and biosolids. Soils. 2006;38(5):578-83. https://doi.org/10.1016/ S1872-2032(06)60052-8.

19. Peralta JR, Gardea-Torresdey JL, Tiemann KJ, Gomez E, Arteaga S, Rascon E, et al. Uptake and effects of five heavy metals on seed germination and plant growth in alfalfa (Medicago sativa L.). Bull Environ Contam Toxicol. 2001:66(6):727-34. https://doi.org/10.1007/s001280069.

20. Ma $M$, Gong $H$, Deng $H$. Effects of heavy metal stress on seed germination and seedling growth of eight urban plants. Chin Agric Sci Bulletin. 2012; 28(22):206-11. https://doi.org/10.1007/s11783-011-0280-z.

21. Hasan SA, Fariduddin Q, Ali B, Hayat S, Ahmad A. Cadmium: toxicity and tolerance in plants. J Environ Biol. 2009;30(2):165-74.

22. Liu XQ Peng KJ, Wang AG, Lian CL, Shen ZG. Cadmium accumulation and distribution in populations of Phytolacca americana $\mathrm{L}$. and the role of 
transpiration. Chemosphere. 2010;78(9):1136-41. https://doi.org/10.1016/j. chemosphere.2009.12.030.

23. Schützendübel A, Polle A. Plant responses to abiotic stresses: heavy metalinduced oxidative stress and protection by mycorrhization. J Exp Bot. 2002; 53(372):1351-65. https://doi.org/10.1093/jxb/53.372.1351.

24. Guo Z, Yuan $\mathrm{H}$, Yansong AO. Effect of cadmium on photosynthesis and nutrient elements uptake of Solanum nigrum L. seedlings. Ecology \& Environmental Sciences. 2009.

25. Foy CD, Chaney RL, White MC. The physiology of metal toxicity in plants. Annu Rev Plant Physiol. 1978;29(1):511-66. https://doi.org/10.1146/annurev. pp.29.060178.002455.

26. Liu SL, Shi XS, Pan YZ, Ding JJ, He Y, Wang L. Effects of cadmium stress on growth,accumulation and distribution of biomass and nutrient in Catharanthus roseus. Acta Pratacul Sin 2013; 22(3):154-161.

27. Sun YB, Zhou QX, Wang L, Liu WT, Liu R. Characteristics of cadmium tolerance and bioaccumulation of Bidens pilosa $\mathrm{L}$. seedlings. Environ Sci. 2009;30(10):3028 http://dx.doi.org/.

28. Liu ZL, He XY. Lonicera japonica Thunb--a newly discovered cd hyperaccumulator. Ecol Environ Sci. 2013;22(4):666-70.

29. Xin NZ, Na SL, Sun TH. Enrichment characteristics of $\mathrm{cd}$ and Pb by four kinds of plant under hydroponic culture. Chin J Ecol. 2010;29:261-8. https:// doi.org/10.1016/S1872-5813(11)60001-7.

30. Zhang $Z$, Wang $H$, Wang $X, B i Y$. Nitric oxide enhances aluminum tolerance by affecting cell wall polysaccharides in rice roots. Plant Cell Rep. 2011;30: 1701-11. https://doi.org/10.1007/s00299-011-1078-y.

31. Krzesłowska M. The cell wall in plant cell response to trace metals: polysaccharide remodeling and its role in defense strategy. Acta Physiol Plant. 2011;33:35-51. https://doi.org/10.1007/s11738-010-0581-z.

32. Harmita H, Karthikeyan KG, Pan XJ. Copper and cadmium sorption onto Kraft and organosolv lignins. Bioresour Technol. 2009;100(24):6183-91. https://doi.org/10.1016/j.biortech.2009.06.093.

33. Chabannes M, Ruel K, Yoshinaga A, Chabbert B, Jauneau A, Joseleau JP, Boudet AM. In situ analysis of lignins in transgenic tobacco reveals a differential impact of individual transformations on the spatial patterns of lignin deposition at the cellular and subcellular levels. Plant J. 2001;28(3): 271-82. https://doi.org/10.1046/j.1365-313X.2001.01159.x.

34. Liu SL, Yang RJ, Ma MD, Jiang P, Zhao Y. Effects of soil cadmium on growth and physiological characteristics of Solanum nigrum L. Plants J Agro Environ Sci. 2015;34(2):240-7.

35. Cao XD, Ma LQ, Tu C. Antioxidative responses to arsenic in the arsenichyperaccumulator Chinese brake fern (Pteris vittata L.). Environmental Pollution. 2004;128(3):317-25. https://doi.org/10.1016/j.envpol.2003.09.018.

36. Vázquez MD, Poschenrieder C, Barceló J, Baker AJM, Hatton PV, Cope GH. Compartmentation of zinc in roots and leaves of the zinc Hyperaccumulator Thlaspi caerulescens J \& C Presl. Plant Biol. 1994;107(4):243-50. https://doi. org/10.1111/j.1438-8677.1994.tb00792.x.

37. RodríguezSerrano M, RomeroPuertas MC, Pazmiño DM, Testillano PS, Risueño MC, Río LAD, et al. Cellular response of pea plants to cadmium toxicity: cross talk between reactive oxygen species, nitric oxide, and calcium. Plant Physiol. 2009;150(1):229-43. https://doi.org/10.1104/pp.108.131524.

38. Shao G, Hassan MJ, Zhang $X$, Zhang G. Effects of cadmium stress on plant growth and antioxidative enzyme system in different rice genotypes. Chin J Rice Sci. 2004;18(3):239-44. https://doi.org/10.1007/s11769-003-0051-2.

39. Sharma SS. The significance of amino acids and amino acid-derived molecules in plant responses and adaptation to heavy metal stress. J Exp Bot. 2006;57(4):711-26. https://doi.org/10.1093/jxb/erj073.

40. Kováčik J, Klejdus B, Hedbavny J, Bačkor M. Effect of copper and salicylic acid on phenolic metabolites and free amino acids in Scenedesmus quadricauda (Chlorophyceae). Plant Sci. 2010;178(3):307-11. https://doi.org/ 10.1016/j.plantsci.2010.01.009.

41. Mishra S, Srivastava S, Tripathi RD, Govindarajan R, Kuriakose SV, Prasad MNV. Phytochelatin synthesis andresponse of antioxidants during cadmium stress in Bacopamonnieri L. Plant Physiol Biochem. 2006;44(1):25-37. https:// doi.org/10.1016/j.plaphy.2006.01.007.

42. Połeć-Pawlak K, Ruzik R, Abramski K, Ciurzyńska M, Gawrońska H. Cadmium speciation in Arabidopsis thaliana as a strategy to study metal accumulation system in plants. Anal Chim Acta. 2005;540(1):61-70. https://doi.org/10.1016/ j.aca.2004.10.048.

43. Benavides MP, Gallego SM, Tomaro ML. Cadmium toxicity in plants. Braz J Plant Physiol. 2005;17(1):21-34. https://doi.org/10.1590/S167704202005000100003 .
44. Sun RL, Zhou QX, Jin CX. Cadmium accumulation in relation to organic acids in leaves of Solanum nigrum L. as a newly found cadmium hyperaccumulator. Plant Soil. 2006;285(1-2):125-34. https://doi.org/10.1007/ s11104-006-0064-6.

45. Sun RL. Analysis on Ecological characteristics and pollution tolerance Mechanism of cadmium Superaccumulative plants. Shenyang: Shenyang Institute of Applied Ecology, Chinese Academy of Sciences; 2006.

46. Lu H, Yan C, Liu J. Low-molecular-weight organic acids exuded by mangrove ( Kandelia candel (L.) Druce) roots and their effect on cadmium species change in the rhizosphere. Environ Exp Bot. 2007;61 (2):159-66. https://doi.org/10.1016/j.envexpbot.2007.05.007.

47. Lequeux H, Hermans $\mathrm{C}$, Lutts S, Verbruggen N. Response to copper excess in Arabidopsis thaliana: impact on the root system architecture, hormone distribution, lignin accumulation and mineral profile. Plant Physiol Biochem. Plant Physiol Biochem. 2010;48(8):673-82. https://doi.org/10.1016/j.plaphy. 2010.05.005

48. Babula P, Klejdus B, Kovacik J, Hedbavny J, Hlavna M. Lanthanum rather than cadmium induces oxidative stress and metabolite changes in Hypericum perforatum. J Hazard Mater. 2015;286:334-42. https://doi.org/10. 1016/j.jhazmat.2014.12.060.

49. Tattini M, Galardi C, Pinelli P. Differential accumulation of flavonoids and hydroxycinnamates in leaves of Ligustrum vulgare under excess light and drought stress. New Phytol. 2004;163(3):547-61. https://doi.org/10.1111/j. 1469-8137.2004.01126.x.

50. Ogundiwin EA, Peace CP, Nicolet CM, Rashbrook VK, Gradziel TM, Bliss FA, et al. Leucoanthocyanidin dioxygenase gene (PpLDOX): a potential functional marker for cold storage browning in peach. Tree Genet Genomes. 2008;4(3): 543-54. https://doi.org/10.1007/s11295-007-0130-0.

51. Kreuzaler F, Hahlbrock K. Enzymatic synthesis of aromatic compounds in higher plants: formation of naringenin (5,7,4'-trihydroxyflavanone) from pcoumaroyl coenzyme a and malonyl coenzyme a. Historical patterns of industrialization /: Longman; 1972. https://doi.org/10.1016/00145793(72)80679-3.

52. Vogt T. Phenylpropanoid biosynthesis. Mol Plant. 2010;3(1):2-20. https://doi. org $/ 10.1093 / \mathrm{mp} / \mathrm{ssp} 106$.

53. Christie PJ, Alfenito MR, Walbot V. Impact of low-temperature stress on general phenylpropanoid and anthocyanin pathways: enhancement of transcript abundance and anthocyanin pigmentation in maize seedlings. Planta. 1994;194(4):541-9. https://doi.org/10.1007/bf00714468.

54. Izbiańska K, Arasimowiczjelonek M, Deckert J. Phenylpropanoid pathway metabolites promote tolerance response of lupine roots to lead stress. Ecotoxicol Environ Saf. 2014;110:61-7. https://doi.org/10.1016/j.ecoenv.2014. 08.014 .

55. Haag-Kerwer A. Cadmium exposure in brassica juncea causes a decline in transpiration rate and leaf expansion without effect on photosynthesis. Exp Bot. 1999;50(341):1827-35. https://doi.org/10.1093/jexbot/50.341.1827.

56. Chen F, Wang F, Sun H, Cai Y, Mao W, Zhang G, et al. Genotype-dependent effect of exogenous nitric oxide on cd-induced changes in Antioxidative metabolism, ultrastructure, and photosynthetic performance in barley seedlings (Hordeum vulgare). J Plant Growth Regul. 2010;29:394-408. https:// doi.org/10.1007/s00344-010-9151-2.

57. Tezara W, Martínez D, Rengifo E, Herrera A. Photosynthetic responses of the tropical spiny shrub Lycium nodosum (Solanaceae) to drought, soil salinity and saline spray. Ann Bot. 2003;92(6):757-65. https://doi.org/10.1093/aob/ mcg199.

58. Nield J, Orlova EV, Morris EP, Gowen B, Heel MV, Barber J. 3D map of the plant photosystem II supercomplex obtained by cryoelectronmicroscopy and single particle analysis. Nat Struct Biol. 2000;7(1):44-7. https://doi.org/10. 1038/71242.

59. Li HS. Principles and techniques of plant physiology and Biochemistry Experiments. In: Xiong QE editors. Plant Physiology Experiment Course. Sichuan Science and Technology Press p. 2003;68-92.

60. Dong W. Germination testing methods on achnatherum splendens seeds. Prataculturalence. 1998.

61. Pan YH, Wang HB, Gu ZP. Accumulation and translocation of heavy metals by macrophytes. Acta Ecol Sin. 2010;30(23):6430-41. https://doi.org/10.1016/ S1872-5813(11)60001-7.

62. Bai Z, Wang T, Wu Y, Wang K, Liang Q, Pan Y, et al. Whole-transcriptome sequence analysis of differentially expressed genes in Phormium tenax under drought stress. Sci Rep. 2017;7:41700. https://doi.org/10.1038/ srep41700. 
63. Wang K, Zhong M, Wu YH, Bai ZY, Liang QY, Liu QL, et al. Overexpression of a chrysanthemum transcription factor gene DgNAC1 improves the salinity tolerance in chrysanthemum. Plant Cell Rep. 2017;36:1-11. https://doi.org/ 10.1007/s00299-017-2103-6.

64. Cakmak I, Marschner H. Magnesium deficiency and high light intensity enhance activities of superoxide dismutase, ascorbate peroxidase, and glutathione reductase in bean leaves. Plant Physiol. 1992;98(4):1222-7. https://doi.org/10.1104/pp.98.4.1222.

65. Beauchamp C, Fridovich I. Superoxide dismutase: improved assays and an assay applicable to acrylamide gels. Anal Biochem. 1971;44:276-87. https:/ doi.org/10.1016/0003-2697(71)90370-8.

66. Nakano Y, Asada K. Hydrogen peroxide is scavenged by Ascorbate-specific peroxidase in spinach chloroplasts. Plant Cell Physiol. 1981;22:867-80. https://doi.org/10.1093/oxfordjournals.pcp.a076232.

67. Quessada MP, Macheix JJ. Caracterisation d'une peroxydase impliquee specifiquement dans la lignification, en relation avec l'incompatibilite au greffage chez l'abricotier. Physiologie Vegetale. 1984.

68. Irigoyen JJ, Emerich DW, Sanchez-Diaz M. Water stress induced changes in concentrations of proline and total soluble sugars in nodulated alfalfa (Medicago sativa) plants. Physiol Plant. 1992;84(1):55-60. https://doi.org/10. 1111/j.1399-3054.1992.tb08764.x.

69. Mguis K, Abassi M, Khadhri A, Ykoubi-Tej M, Mahjoub A, Brahim NB, et al. Responses of leaf growth and gas exchanges to salt stress during reproductive stage in wild wheat relative Aegilopsgeniculata Roth. And wheat (Triticumdurum Desf.). Acta Physiol Plant. 2013;35(5):1453-61. https:// doi.org/10.1007/s11738-012-1185-6.

70. Chang XF, Chandra R, Berleth T, Beatson RP. Rapid, microscale, acetyl bromide-based method for high-throughput determination of lignin content in Arabidopsis thaliana. J Agric Food Chem. 2008;56(16):6825-34. https://doi.org/10.1021/jf800775f.

71. Dedaldechamp F, Uhel C, Macheix JJ. Enhancement of anthocyanin synthesis and dihydroflavonol reductase (DFR) activity in response to phosphate depriviation in grape cell suspensions. Phytochemistry. 1995; 40(5):1357-60. https://doi.org/10.1016/0031-9422(95)00480-u.

72. Anders $\mathrm{S}$, Huber W. Differential expression analysis for sequence count data. Genome Biol. 2010;11:R106. https://doi.org/10.1186/gb-2010-11-10-r106.

73. Benjamini Y, Hochberg Y. Controlling the false discovery rate: a practical and powerful approach to multiple Testing. J. R. stat. Soc. B stat. Methodol. 1995;57(1):289-300.

\section{Publisher's Note}

Springer Nature remains neutral with regard to jurisdictional claims in published maps and institutional affiliations.

Ready to submit your research? Choose BMC and benefit from:

- fast, convenient online submission

- thorough peer review by experienced researchers in your field

- rapid publication on acceptance

- support for research data, including large and complex data types

- gold Open Access which fosters wider collaboration and increased citations

- maximum visibility for your research: over $100 \mathrm{M}$ website views per year

At $\mathrm{BMC}$, research is always in progress.

Learn more biomedcentral.com/submissions 